\title{
La figura de Jesús en el Apocalipsis
}

\author{
Xavier Alegre, \\ Facultad de Teología de Cataluña, Barcelona, \\ Centro de Reflexión Teológica, San Salvador
}

\section{Introducción}

Permítanme ${ }^{1}$ que hoy empiece contándoles una anécdota. Cuentan que en una ocasión, una pareja celebraba sus bodas de plata. El marido estaba en la puerta de la casa e iba anunciando a su esposa las personas que iban llegando para la celebración. Decía: "Cariño, los Martínez". "Vida mía, los Pérez". "Mi amor, los Rodríguez". "Luz de mi vida, los Gutiérrez", y así todo el rato. Un amigo se le acercó y le dijo: "Me parece bien que después de tantos años tengas tanto cariño a tu mujer. Pero, ¿no exageras un poco? ¿No bastaría con decir su nombre?". A lo que él contestó: "Si quieres que te diga la verdad, es que no recuerdo su nombre de pila".

¿Por qué cuento esto? Porque en el Apocalipsis, uno se queda sorprendido por la cantidad enorme de títulos que su autor aplica a Jesús. Pero en este caso no es ciertamente porque haya olvidado su nombre. Sale 7 veces el nombre de Jesús solo $^{2}$. Siete es un número de plenitud. Y la mención de Jesús, sin añadir "Cristo", invita a fijarse en su humanidad ${ }^{3}$. El motivo de tantos títulos, por tanto, ha de ser más bien otro. Y pienso que está en consonancia con lo que, de otro modo, intenta también el autor del cuarto Evangelio, que forma parte del mismo círculo eclesial al que pertenece el autor del Apocalipsis.

1. En el origen de este artículo está una conferencia que di en Donostia (España) en enero de 2013.

2. En Ap 1, 9; 12, 17; 14, 12; 17, 6; 19, 10; 20, 4; 22, 16 (en cuatro ocasiones, se habla de su testimonio; en una, de su fe o fidelidad). Estos textos están enmarcados por otros tres que hablan de "Jesús Cristo o Mesías" (Ap 1, 1.2.5) y dos que hablan del "Señor Jesús" (Ap 22, 20.21).

3. Cfr. J. Comblin, Cristo en el Apocalipsis, Barcelona, 1969, p. 30, n. 25. 
En el cuarto Evangelio, su autor, y de un modo ciertamente genial, intenta, por un lado, subrayar la encarnación, la humanidad de Jesús (ningún otro Evangelio señala tantas veces la humanidad de Jesús, hasta hacer decir a los adversarios de Jesús que no lo quieren matar por sus obras, sino porque siendo hombre como es, pretende ser igual a Dios: Jn 10, 33; cfr. Jn 1, 14; 1 Jn 4, 2). Pero, por otro lado, el evangelista procura mostrar, por activa y por pasiva, la divinidad de Jesús, su relación única con el Padre, hasta llegar a la confesión de Tomás referida a Jesús resucitado: “¡Señor mío y Dios mío!” (Jn 20, 28).

Creo que el profeta Juan ( $c f r$. Ap 22, 9; también 1,3) se plantea un reto semejante en el Apocalipsis, aunque lo explicita desde un talante teológico distinto y sin la radicalidad con la que el evangelista es capaz de formular la divinidad de Jesús.

De hecho, como he recordado antes, el nombre de Jesús, que le aplica 7 veces, recuerda la humanidad de este, algo incuestionable para el autor, pues murió en una cruz (insiste en que es el Cordero degollado). Pero la Resurrección le ha hecho comprender el misterio profundo de Jesús ${ }^{4}$. Por eso, la enorme cantidad de títulos que le aplica pretende ayudar a comprender el misterio hondo de este Jesús, que gracias sobre todo a su muerte y Resurrección (es el "Cordero degollado de pie ante el trono de Dios"), se convierte en el mediador del Padre, en el Salvador de la Iglesia y en el Juez universal. No se atreve a llamarle Dios, como sí lo hará el cuarto evangelista, pero la divinidad de Jesús está implícita en el modo como lo va presentando a lo largo de su obra ${ }^{5}$.

Por eso se ha dicho, con razón, que sin la figura de Jesús, que es como el hilo conductor que enlaza todas las imágenes, símbolos y escenas, a la vez que

4. Por eso dice J. P. Prévost, Para leer el Apocalipsis, Estella, 1994, p. 18: "Esta es la gran originalidad del Apocalipsis: haber sabido desvelar las implicaciones para el mundo presente, de la muerte-resurrección de Jesús. Se advertirá hasta qué punto Juan ha sabido retener las dos facetas inseparables de este único misterio (Cristo se presenta como 'el que vive', pero no sin recordar que 'estuvo muerto', y el Cordero victorioso aparece como 'degollado'). Al recoger las dos facetas del misterio, Juan no deja sin embargo ninguna duda sobre el resultado de este acontecimiento decisivo: es el polo de la resurrección el que ilumina tanto la muerte del Señor crucificado (un acontecimiento pasado) como el presente y el porvenir de los creyentes (la lucha con la Bestia y la suerte final de la humanidad, representada aquí por la nueva Jerusalén)".

5. F. Contreras Molina saca esta conclusión de su estudio sobre la cristología del Apocalipsis: "A través del testimonio de todas sus páginas, sirviéndose de recursos sutiles, el libro pretende llevar al ánimo del lector cristiano, entonces perseguido a causa de su fe, una convicción fundamental: la divinidad de Cristo" (El Señor de la vida. Lectura cristológica del Apocalipsis, Salamanca, 1991, p. 349; cfr. pp. 348-352). 
infunde un tono de serenidad a toda la historia dramática que está viviendo la comunidad, el Apocalipsis se desintegraría en escenas poco coherentes ${ }^{6}$.

Sin embargo, no es precisamente la "alta cristología” lo que de entrada solemos asociar con el Apocalipsis ${ }^{7}$. De hecho, el libro tiene muy mala prensa, debido a la identificación errónea entre la palabra "apocalipsis" y las catástrofes que acompañan el fin del mundo, por lo cual es importante que situemos al Apocalipsis en su clave adecuada de interpretación. Por ello cito un texto de P. C. Núñez ${ }^{8}$, que presenta muy bien el marco en el que se debe leer la figura de Jesús que se revela en el último libro de la Biblia:

El Apocalipsis es la Revelación de Jesucristo sobre Jesucristo, en forma de carta pastoral profética y contestataria de un pastor perseguido y deportado, llena de mensaje esperanzador, escrita en términos apocalípticos a una Iglesia brutalmente perseguida y que, además, padece crisis interna, para animarla a una lucha tenaz, perseverante y sin cuartel hasta el final y, para comunicarle que, en contra de las apariencias, quien saldrá vencedor, sin género de dudas, es Cristo.

Pienso que, de un modo resumido, Núñez nos da aquí las claves para entender el Apocalipsis, pues al ser una denuncia decidida de la injusticia del Imperio romano, que lo domina todo y persigue a los cristianos, el autor, como buen apocalíptico, se ve obligado a utilizar un lenguaje cifrado, simbólico, para evitar que los no iniciados - sobre todo, el Imperio romano - comprendan el mensaje y persigan aún más radicalmente a la Iglesia.

Teniendo esto presente, quiero insistir en que la clave fundamental del Apocalipsis se encuentra, como se sabe, en el hecho de que este libro es, ante todo, "una buena noticia (Evangelio) eterna" (Ap 14, 6), que llena de felicidad a los que escuchan su mensaje y lo ponen en práctica ( 7 bienaventuranzas! $!^{9}$ ).

6. Cfr. A. Läpple, "El misterio del Cordero", Selecciones de Teología, 25 (1986), p. 64. En la misma línea observa Prévost, Para leer, 13: "Lo extraño es que se haya leído este libro sin percibir a aquel que sostiene toda su arquitectura. La figura central es Cristo muerto y resucitado".

7. De hecho, Lutero llega a afirmar en su prólogo al Apocalipsis de 1522 que en él, "Cristo ni es enseñado ni es reconocido". Y R. Bultmann afirmaba en su Teología del Nuevo Testamento (Salamanca, 1981, p. 603), que "debemos catalogar el cristianismo de Ap como un judaísmo débilmente cristianizado". En cambio, para G. R. Beasley-Murray, "The contribution of the Book of Revelation to the Christian Belief in Immortality", SJTh, 27 (1974), no hay otro libro en el Nuevo Testamento que contenga una cristología más elevada.

8. P. C. Núñez, ¿Fuertes o débiles? Las siete Iglesias del Apocalipsis ayer y hoy, Bilbao, 2007, p. 21.

9. Cfr. Ap 1, 3; 14, 13;16, 15;19, 9;20, 6; 22, 7; 22, 14. Sobre el significado global del Apocalipsis, publiqué dos artículos en esta revista: "El Apocalipsis, memoria subversiva y fuente de esperanza para los pueblos crucificados", RLT, 9 (1992), pp. 201-230. 
Es un "evangelio" revelado por Dios al profeta Juan $-\mathrm{y}$, a través de él, a los creyentes-, para ayudarle a discernir, ante todo, desde la fe, lo que está ocurriendo en el mundo. Para ello, desenmascara al ídolo imperial, que quiere engañar a la Iglesia (y al mundo entero) y persigue a los cristianos que no están dispuestos a adorar a la Bestia (cfr. Ap 13), expresión simbólica del Imperio romano (y de todo imperio). Y, a la vez, quiere animar a la Iglesia a resistir al Imperio y a sus colaboradores, manteniendo viva la esperanza en Dios, el cual, al resucitar a Jesús de entre los muertos, ha revelado quién es realmente el Señor y Dueño del mundo y de la historia, pues no lo es Domiciano, simbolizado en el número $666(c f r \text {. Ap 13, 18) })^{10}$, a pesar de sus pretensiones y de su aparentemente inmenso poder.

Y Juan lo hace recordando también que Dios protege a la Iglesia y la encamina hacia el cielo nuevo y la nueva tierra, la Jerusalén celestial, en la que no habrá ya ni llanto ni luto, ni dolor, porque Dios lo será todo en todos ( $c f r$. Ap 21, $1-22,5)^{11}$. Un Dios que se hace presente poderosamente en la historia, precisamente, a través de Jesús, que es la revelación y el instrumento de Dios en este mundo y en esta historia que están viviendo los cristianos.

¿Qué dice, entonces, el Apocalipsis sobre Jesús, cómo presenta su figura, que, como intentaré mostrar, es fundamental en este último libro de la Biblia cristiana?

Para explicarlo, hablaré primero, partiendo del misterio de la íntima unión de Jesús con el Padre y el Espíritu, de los numerosos títulos que Juan atribuye a Jesús en su obra. En segundo lugar, mostraré que Jesús es el revelador del curso de la historia y del sentido de la vida humana. Y, por último, presentaré a Jesús como protector amoroso y guía crítico de la Iglesia ${ }^{12}$. Con ello, espero poder

293-324 (también en X. Alegre, Memoria subversiva y esperanza para los pueblos crucificados, Madrid, 2003, pp. 25-66); y "Resistencia cristiana y esperanza profética. Lectura del Apocalipsis de Juan desde las víctimas", RLT, 19 (2002), pp. 3-24 (también en X. Alegre, La palabra no está encadenada, San Salvador, 2009, pp. 53-84). Cfr. también X. Alegre, El Apocalipsis de Juan. El libro de la resistencia y esperanza cristiana en un mundo injusto, San Salvador, 2009 (Cuadernos Mons. Romero, 23).

10. Cfr. J. O. Tuñí y X. Alegre, Escritos joánicos y cartas católicas, Estella, 1995, pp. 280 y s.

11. Una presentación resumida del Apocalipsis puede verse en X. Alegre, Resistencia y esperanza cristianas en un mundo injusto. Introducción al Apocalipsis, Barcelona, 2010 (Cuadernos CCJ, 165).

12. Son los tres aspectos fundamentales que explicitan la figura del Señor en el Apocalipsis, según Contreras (El Señor de la vida, op. cit., p. 344): "Se cumple, realizada en Cristo, la aspiración del Salmo $(36,10)$ : En la luz del Señor vemos la luz de Dios, de la Iglesia y de la historia". 
mostrar cómo es el Jesús que nos revela el Apocalipsis y por qué su mensaje sigue siendo tan válido para nosotros hoy.

\section{El misterio más hondo de Jesús es su íntima unión con el Padre y el Espíritu}

El Apocalipsis es, de entrada, como nos lo indica el profeta Juan ya en el título de su obra, "una revelación de Jesucristo sobre Jesucristo" (Ap 1, 1a). Es, pues, un libro eminentemente cristológico.

Pero conviene tener presente que, en último término, es una revelación del Padre, pues Él ha dado la revelación a Jesús (Ap 1, 1b) para que la comunique a sus siervos, es decir, a los miembros de la Iglesia. En este sentido, Jesucristo es el gran revelador de lo que el Padre quiere comunicar y, en definitiva, del Padre mismo, un motivo que desarrolla sobre todo el Evangelio de Juan, que reflexiona a fondo sobre las relaciones entre el Padre y el Hijo.

Ya de entrada, el autor nos indica que ante todo nos quiere ofrecer "una revelación", pues esto es lo que significa la palabra griega "apocalypsis", por cuanto el misterio más hondo de Jesús (y de la historia, marcada por su presencia) solo se puede conocer por revelación de Dios. Una revelación que, en último término, es una revelación de Dios Padre, gracias a la unión íntima que hay entre Dios y Jesucristo, que es el receptor de la revelación del Padre.

Pero esta revelación, Dios la ha querido comunicar a su pueblo escogido, a su Iglesia, que ha sido llamada por Dios, a través precisamente de Jesús, para ser su instrumento liberador en este mundo injusto, un mundo, el del Imperio romano (y el de todo imperio), que no se quiere convertir al proyecto de Dios, a pesar de que las plagas que está experimentando ( $c f r$. Ap 14, 6-19, 8) lo están invitando a tomar conciencia de lo errado de su camino y de la necesidad de su conversión (cfr. cuarto septenario).

Pero el libro no contiene una revelación, en principio secundaria, de lo que está ocurriendo y va a ocurrir en el mundo, sino una revelación de Jesucristo (eso es lo que implica el genitivo griego, en cuanto es un genitivo subjetivo, con el que Juan califica la palabra "revelación") ${ }^{13}$, que a través de este libro se comunica con la comunidad. Pero es también, en cuanto el genitivo griego puede ser también objetivo, una revelación sobre Jesucristo. Y no es una revelación cualquiera, pues

13. Esto viene confirmado, p. ej., por el hecho de que Juan, cuando pone la fórmula "táde légei ho", en las 7 cartas de Ap 2-3, está aludiendo a la introducción que los profetas del Antiguo Testamento ponen a sus palabras, para indicar que están hablando en nombre de Yahvé ( $c f r$. Jer 2, 1; 6, 16.22; Am 2, 1, etc.). Se presenta, pues, como portavoz de Cristo, a semejanza de lo que hacen los profetas del Antiguo Testamento (cfr. H. Giesen, Die Offenbarung des Johannes, Regensburg, 1997, p. 93). Con ello da una relevancia especial, divina, a las palabras de Cristo. 
se trata de la que Dios ha dado a Jesús para que la muestre a los cristianos (Ap 1, 1b), confiándoles una misión por cuanto él necesita a la Iglesia para poder llevar a cabo su proyecto liberador en este mundo ( $c f r$. el septenario de las trompetas: Ap 8, 2-14, 5) ${ }^{14}$.

Teniendo esto presente, veamos ahora las numerosas afirmaciones (un auténtico tratado de cristología) que el Apocalipsis hace sobre Jesús, sobre todo tal como este aparece ahora, resucitado ${ }^{15}$, a la comunidad. En cuanto a la vida terrena de Jesús, el Apocalipsis habla solo de los hechos más fundamentales (su encarnación y su muerte), pues la vida de Jesús ya la recuerdan los cuatro Evangelios, que utilizan para ello un género literario distinto, un género que, siguiendo a Marcos, denominamos "evangelio". Por ello, la imagen de Jesús que presenta el Apocalipsis no es la del Jesús terreno (aunque, como dije antes, sorprende el hecho de que utiliza, sin calificación alguna, 7 veces el nombre de Jesús: 1,$9 ; 12,17 ; 14,12 ; 17,6 ; 19,10 ; 20$, 4; 22, 16), sino la del Jesús glorificado, tal como es confesado y se hace presente en la comunidad, en las Iglesias cristianas, a las que el profeta Juan dirige su libro, pues es su presencia poderosa o su ausencia lo que preocupa a las comunidades perseguidas. En este sentido, Juan nos ofrece un auténtico tratado de cristología ${ }^{16}$, pues los distintos títulos nos van

14. No olvidemos que Dios, según la Biblia, actúa en el mundo, respetando la libertad humana (se puede rechazar la revelación), precisamente revelándose. Pablo lo indica claramente en Rom 1, 16-17, cuando afirma que el Evangelio es una Buena Noticia por cuanto es una fuerza de Dios, salvadora y universal ( $c f r$. Rom 1, 16), precisamente en cuanto en él se revela la justicia salvadora de Dios que brota de la fe y apunta a la fe (cfr. Rom 1, 17).

15. Sobre el significado de la Resurrección y exaltación de Jesús en el Apocalipsis, $c f r$. F. Contreras, El Señor de la vida, op. cit., pp. 347-349. El significado de la Resurrección lo subraya también Comblin: "Por la Resurrección mostró Jesús que tenía poder sobre la vida y la muerte: tiene las llaves de la muerte y del Hades $(1,18)$ por una parte, y por otra parte tiene la llave de David; cuando él abre, nadie puede cerrar, y cuando cierra, nadie puede abrir $(3,7)$. La llave de David es seguramente la de la vida, la de Sión, la de la nueva Jerusalén. Jesús es, por tanto, señor de la muerte y de la vida" (Cristo en el Apocalipsis, op. cit., pp. 114), indicando en la n. 67: "Se trata de un poder divino según las concepciones judías contemporáneas".

16. Sobre la cristología del Ap puede consultarse: J. Comblin, Cristo en el Apocalipsis (Barcelona, 1969), у T. Holtz, Die Christologie der Apokalypse des Johannes (Berlín, ${ }^{2} 1971$ ); F. Bovon, "Le Christ de l'Apocalypse", RThPh, 21 (1972), pp. 65-80 (condensado en Selecciones de Teología, 13 [1974], pp. 45-49); Prévost, Para leer el Apocalipsis, op. cit., pp. 13-21; R. Guardini, Imagen de Jesús, el Cristo, en el Nuevo Testamento, Madrid, 1969, pp. 89-109; R. Schnackenburg, "La figura de Cristo en el Apocalipsis", en Mysterium salutis, III/1, Madrid, 1969, pp. 392-401; T. B. Slater, Christ and Community. A Socio-Historical Study of the Christology of Revelation, Sheffield, 1999 (destaca la dimensión pragmática del Apocalipsis); K. Huber, "Jesus der Christus, der Erste und der Letzte: Zur Christologie der Johannesapokalypse”, 
descubriendo el ser más hondo y el significado profundo de la persona de Jesús ${ }^{17}$. Y esta cristología fundamenta la soteriología de la obra en la que Jesús juega el papel fundamental ${ }^{18}$.

\section{Saludo inicial (Ap 1, 4-8)}

Ya en el saludo inicial a las siete Iglesias de Asia, que representan a todas las Iglesias (Ap 1, 4-5), el profeta subraya ante todo la unidad íntima entre el Padre, denominado como "el que es, el que era y ha de venir", el Espíritu (los siete espíritus simbolizan la plenitud de los dones del Espíritu) ${ }^{19}$ y Jesucristo. Esta comunión trinitaria es esencial para poder comprender el misterio más hondo de Jesús.

Pero como Jesucristo es el revelador por excelencia de Dios a través de su encarnación, vida y muerte aquí en la tierra, es calificado, además, como el testigo (mártir) fiel ("y verdadero": cfr. $3,7.14 ; 19,10)^{20}$, que nos ha rescatado de nuestros pecados con su sangre (en la cruz) y como el primer resucitado de entre los muertos (también en Ap 1, 18; 2, 8; cfr. Rm 8, 29; Col 1, 18).

$\mathrm{Y}$ eso es lo que le ha convertido en el soberano de los reyes de la tierra (una crítica a la pretensión de Domiciano de ser adorado como Dios y Señor), cumpliéndose en él la promesa de Dios a David, según Is 55, 4: "Yo le constituí mi testigo ante los pueblos, caudillo y señor de las naciones", pues Jesús es el Mesías prometido (cfr. Ap 3, 7; 5, 5; 22, 16).

Notemos que para el autor del Apocalipsis, la cruz tiene un significado fundamental, soteriológico, para los que forman la Iglesia, pues es con su sangre como Cristo nos ha lavado y redimido de nuestros pecados ( $c f r$. Ap 1, 5; 5,

en J. Frey, J. A. Kelhoffer y F. Töth, Die Johannesapokalypse. Kontexte, Konzepte, Rezeption, Tübingen, 2012, pp. 435-472; K. Huber, Einer gleich einem Menschensohn. Die Christusvisionen in Offb 1, 9-20 und Offb 14, 14-20, und die Christologie der Johannesoffenbarung, Münster, 2007 (en las pp. 16-73, el autor nos da una visión de conjunto de la investigación anterior sobre la cristología del Apocalipsis).

17. Prévost habla de "un Cristo deslumbrador" (, Para leer el Apocalipsis, op. cit., p. 16).

18. Sobre la soteriología del Apocalipsis, $c f r$. K. Huber, Einer gleich einem Menschensohn, op. cit., pp. 299-301.

19. Según F. Contreras, la palabra "espíritu", que sale 24 veces en la obra, "se revela fundamentalmente como Espíritu de profecía, que ayuda a la Iglesia a entender sabiamente, a interiorizar la palabra del Señor y a ser capaz de proclamarla ante el mundo" (El Señor de la vida, op. cit., p. 25; cfr. pp. 355-357; y cita, entre otras, su obra El Espíritu en el libro del Apocalipsis, Salamanca, 1987); cfr. también Comblin, Cristo en el Apocalipsis, op. cit., pp. 256-259.

20. El significado de Jesús (y del cristiano) como "testigo" y el de la palabra "testimonio" en el Apocalipsis, lo trata ampliamente Comblin, Cristo en el Apocalipsis, op. cit., pp. 191-231. 
9; 7, 14 ${ }^{21}$. En sintonía con el Evangelio de Juan, donde Jesús era visto como "el cordero de Dios que quita el pecado del mundo" (Jn 1, 29; $c f r .1,36)$ y moría en el momento en el cual el cordero pascual era sacrificado en el templo ( $c f r$. Jn 19), el título de "Cordero inmolado" es muy significativo en el Apocalipsis ${ }^{22}$. Pues es como Cordero inmolado, de pie ante el trono (resucitado), como ha obtenido la capacidad de interpretar la historia, rompiendo los siete sellos del libro que la simboliza ( $c f r$. Ap 5, 4-8). Y es por la sangre del Cordero que los mártires han podido dar testimonio, venciendo así al diablo (cfr. Ap 12, 10-12). Por eso, para Contreras, el Cordero nos revela la plenitud del misterio del Señor ${ }^{23}$ :

El Cordero (...) representa la síntesis orgánica del misterio todo de Cristo. Con esta formulación brevísima, el Apocalipsis está señalando de manera audaz pero muy elocuente, como una pintura que retrata los rasgos esenciales de la figura de Jesús, muerto y resucitado, lleno del poder mesiánico, Rey de reyes, poseedor y dador del Espíritu, entronizado por Dios en el cielo delante de los ángeles, que ha hecho de toda la humanidad un pueblo regio y sacerdotal, que es adorado en la Iglesia y en el mundo entero, que está pronto para intervenir en la historia y que comparte con Dios el mismo y único trono de la divinidad.

Por otro lado, autores como J. Comblin ${ }^{24}$ ven la figura del Siervo de Yahvé detrás de la figura del Cordero y defienden que el Apocalipsis es una relectura del deutero-Isaías.

21. Sobre el significado salvífico de la muerte de Cristo, entonces y ahora, $c f r$. Contreras El Señor de la vida, op. cit., pp. 345-347, quien comenta (p. 347): "Con el voluntario derramamiento de ella [de la sangre de Jesús], Jesús rescata el linaje humano. No paga a Dios sangre, sino que devuelve a Dios una humanidad transformada, dando un precio valioso y único, su propia sangre, la cual muestra con creces la calidad de su redención”. El Apocalipsis menciona 19 veces explícitamente la sangre.

22. La palabra Cordero sale 28 veces en el Apocalipsis. Pero mientras el cuarto evangelista utiliza la palabra amnós, el profeta Juan prefiere la palabra griega arníon, que puede significar también Carnero, quizás, como sostienen algunos autores, porque así puede expresar su poder con la imagen de los cuernos. Sobre el origen y significado teológico del Cordero, así como su dignidad y protagonismo activo en la historia de la salvación, cfr. F. Contreras, El Señor de la vida, op. cit., pp. 233-342. T. B. Slater, Christ and Community, op. cit., p. 200, nota, con razón, que el Cordero es "the most comprehensive christological image in Revelation".

23. F. Contreras, El Señor de la vida, op. cit., p. 274; cfr. pp. 349-352. Para Contreras (ibid., p. 349), "el objetivo primario del Apocalipsis: confesar a Cristo como Dios".

24. J. Comblin, Cristo en el Apocalipsis, op. cit., pp. 39-77. Contreras, en cambio, ve críticamente esta identificación sin más (cfr. El Señor de la vida, op. cit., pp. 239 y s). Y tampoco acaba de convencerle que su trasfondo sea solo el Cordero pascual (cfr. ibid., pp. 240-243), porque "el Cordero según se presenta en el libro del Apocalipsis posee una originalidad, aún no descifrada. ¿Cómo puede con cierta verosimilitud explicarse el protagonismo del Cordero, capaz de acciones decisivas, a 
Pero no terminan aquí las excelencias de Jesucristo en el prólogo, pues Jesús, además de amarnos, ha hecho de nosotros un linaje real y sacerdotes para su Dios y Padre ( $c f r$. Ap 1, 5-6), algo que en el Antiguo Testamento era propio de Yahvé (cfr. Ex 19, 6). En este saludo, se dice también de Jesús que es el Viniente (Ap 1, 7a $)^{25}$, el que está viniendo continuamente entre las nubes, que simbolizan el nexo entre el cielo, la trascendencia, y la historia humana, una confesión que hace inclusión con la petición al final del libro tanto del Espíritu, como de la Esposa, la Iglesia, de que Jesús venga al fin de la historia para traer la salvación definitiva a este mundo ( $c f r$. Ap 22, 17.20), algo que, según el testimonio de Jesús que recoge el Apocalipsis, está a punto de ser realidad (cfr. Ap 22, 20; $c f r .1,3 \mathrm{~b}$ ).

Y si añade a continuación que "todo ojo lo verá" (Ap 1, 7b), es para señalar su función universal, ya que tenemos la posibilidad todos los seres humanos de encontrarnos con Él, "hasta los que lo traspasaron" (alusión a Zac 12, 10, citado por Jn 19, 37), pues este encuentro no es nunca mérito propio, sino don gratuito del amor de Dios en Jesús, que, como recuerda san Pablo, no murió por los buenos, sino por los pecadores ( $c f r$. Rm 5, 6-9).

Y esa venida de Jesús es la manera como Dios, "el Alfa y la Omega, aquel que es, que viene y que ha venir, el soberano de todo" (Ap 1, 8; $f f r .21,6$ ), se hace presente en el mundo. No por casualidad constatamos, al final del Apocalipsis, que los títulos de Alfa y Omega, el primero y el último (Is 44, 6; 48, 12 lo afirman de Dios), el principio y el fin, se aplican también a Jesucristo ( $c f r$. Ap 22, 13; cfr. también 1, 17 y 2, 8), con lo cual, no solo aparece como preexistente, sino identificado de alguna manera con Dios, pues por el contexto literario queda claro que el personaje que la Iglesia espera que venga al fin de los tiempos es Jesús (cfr. Ap 22, 12.16-17.20). De todos modos, una mejor clarificación de la relación entre el Padre y el Hijo la encontramos en el cuarto Evangelio, que aunque no es del mismo autor, sí parece pertenecer al mismo círculo, que se suele denominar joánico.

Con ello, el profeta Juan ha subrayado la intima unión entre el Padre y el Hijo, una unión que el Evangelio de Juan, que forma parte de la tradición denominada joánica, expresa de modo muy profundo. Y la acción de Jesús sobre la historia y, de modo especial sobre la Iglesia, apunta a que esta no solo sea

partir de un animal pasivo, inerme, que es conducido al matadero (Is 53,7) o al que se le sacrifica para obtener de él sangre abundante y redentora?, ¿de dónde la fuerza del Cordero, su tremenda energía de victoria, aspectos tan destacados y sobresalientes en el Apocalipsis?" (ibid., p. 244). Este último aspecto sí aparece, en cambio, en el trasfondo apocalíptico del Cordero (cfr. ibid., pp. 245-249). Por eso, piensa que Juan se ha inspirado en los tres posibles trasfondos (cfr. ibid., p. 250).

25. Sobre Jesús como "el que viene" en el Apocalipsis, cfr. J. Comblin, Cristo en el Apocalipsis, op. cit., pp. 79-190. 
instrumento de Dios, sino que lo dirija todo para Dios, meta última del obrar de los cristianos (cfr. Ap 1, 6; 5, 9.10).

\section{La visión inicial del semejante a un Hijo de hombre (Ap 1, 14-20)}

Un compendio de cómo Juan ve a Jesús nos lo da en la visión inicial al comienzo del septenario de las cartas (Ap 1, 12-20) ${ }^{26}$. Juan, el vidente, ve a Jesús en medio de los siete candelabros, que representan las siete Iglesias ( $c f r$. Ap 1, 20), como "una especie de figura humana" (Ap 1, 13; cfr. Ez 1, 26). Literalmente, el texto griego habla de "como un hijo de ser humano" o "hijo de hombre", en una clara alusión a Dan 7, 13, que en la tradición sinóptica y joánica es identificado con Jesús ${ }^{27}$ y tiene en la literatura apocalíptica (cfr. también Jn 5, 22-27) una clara relación con el Juicio definitivo, el final.

Esta figura humana es descrita con siete rasgos que expresan una estructura concéntrica ${ }^{28}$ : cabeza, ojos, pies, voz, mano, boca, rostro, que tiene en su centro "su voz como estruendo de aguas caudalosas" (Ap 1, 15b), que evoca la manifestación de Dios al profeta Ezequiel ( $c f r$. Ez 43, 2; 1, 24), una semejanza más entre Jesús y Dios. Por otro lado, si se dice que "vestía una larga túnica y tenía el pecho ceñido con una banda de oro" (Ap 1,13), se está afirmando de él su carácter sacerdotal ${ }^{29}$ y real (solo los reyes llevan el ceñidor en el pecho, pues es

26. Esta visión forma inclusión con la visión final (Ap 22, 12-20), donde Jesús dice de sí mismo que es el Alfa y la Omega, el primero y el último, el principio y el fin, el esperado por el Espíritu y la Esposa (la Iglesia). Si la primera visión apunta más a la acción de Cristo en la Iglesia y en la historia, la última apunta hacia el final de la historia, la venida definitiva de Jesús, fundamento último de la esperanza cristiana, cuando las bodas entre el Cordero y la Esposa llegarán a su plenitud definitiva, superados los dolores y amenazas de este mundo. Sobre la estructura concéntrica en forma de cinco septenarios ( 7 cartas, 7 sellos, 7 trompetas, 7 copas, 7 visiones) del Apocalipsis, $c f r$. X. Alegre, "El Apocalipsis, memoria subversiva y fuente de esperanza", op. cit., pp. 293-299 (también en Memoria subversiva y esperanza para los pueblos crucificados, op. cit., pp. 56-67).

27. Sobre la figura del "hijo del hombre" en el Apocalipsis, y su trasfondo en Daniel 7 y 10, cfr. J. Comblin, Cristo en el Apocalipsis, op. cit., pp. 84-121; K. Huber, Einer gleich einem Menschensohn, op. cit., pp. 123-147.

28. Cfr. J. Delorme e I. Donegani, L’Apocalypse de Jean. Révélation pour le temps de la violence et du desir, vol. I, París, 2010, p. 63.

29. La palabra que Juan emplea aquí para "túnica" (podêrês) aparece 12 veces en la traducción de los LXX y suele designar una parte del vestido del Sumo Sacerdote. "Jesus, muerto y resucitado, es, con el máximo rigor que se requiere y con la riqueza regia y carga simbólica que de él constantemente emana, el único y sumo Sacerdote, lleno de poder que ejercita dentro de la Iglesia, presidiéndola ("El que está en medio de los siete candelabros de oro" [Ap 2, 1]; "Los siete candelabros son las siete Iglesias" [Ap 1, 20]), toda función y acción litúrgica" (F. Contreras, El Señor de la vida, op. cit., pp. 40 y s.; el significado de Cristo como Sumo Sacerdote lo resume en 
un adorno y no una ayuda para poder ceñirse la túnica para el trabajo). Y si "los cabellos de su cabeza eran blancos como la lana y como la nieve" (Ap 1, 14a), se recuerda la apariencia de Dios en Dan 7, 9 y se señala su pertenencia al mundo divino y su eternidad. "Sus ojos como llamas de fuego" (Ap 1, 14b) y "sus pies como bronce en horno de fundición” (Ap 1, 15a), que recuerdan al ángel de Dios de Dan 10, 6, subrayan que Jesús lo ve, conoce, todo (por eso, en Ap 5 ,6 se dirá del Cordero que tiene siete ojos, algo que era característico de Dios, según Zac $4,10)$ y la solidez de su poder, a diferencia de los imperios que tienen los pies de barro ( $c f r$. Dan 2, 34-35).

El hecho de que Jesús tenga en su mano las siete (¡plenitud!) Iglesias revela, si se tiene en cuenta el significado de la derecha en la literatura apocalíptica ( $c f r$. Mt 25, 31-46; Mc 16, 5), que él es el protector de las Iglesias, a las que ama, como nos ha indicado en la introducción ( $c f r$. Ap 1,5). Con la imagen de que "de su boca salía una espada cortante de dos filos" (Ap 1, 16a; $c f r .19,15)$, Juan pone de manifiesto el poder de la palabra de Jesús para salvar y condenar, una imagen que encontramos ya en Is 49, 2; Sab 18, 14-16; (cfr. también Heb 4, 12). Y si en Ap 1, 18a afirma de Jesús que es "el que vive", eso recuerda que Jeremías denomina a Dios “el Viviente" (Jer 10, 10; cfr. Dt 5, 26; Jos 3, 10; 1 Sam 17, 26.36; Sal 42, 3; Sir 18, 1), como también el Apocalipsis lo aplica a Dios, que está sentado en el trono (Ap 4, 9.10; $c f r .15,7)^{30}$. Por eso, Jesús tiene en su poder las llaves de la muerte y del abismo (Ap 1, 18b), es decir, la capacidad de darles la salvación

las pp. 352-354). De todos modos, como matiza Comblin (ibid., p. 265), y a diferencia de Hebreos, "su función sacerdotal y sus atributos sacerdotales están, sin embargo, muy esfumados en el Apocalipsis, e incomparablemente menos destacados que sus atributos reales. Esto se comprende por la razón de que Jesús, estando situado al lado de Dios, es considerado como objeto del culto, más bien que como mediador. A Él se dirige el culto en Ap 5; 7, 9-10; 21, 9-22, 5, al mismo tiempo que a Dios. Por otra parte, en su muerte se lo considera sobre todo como la víctima del sacrificio. Quedaba poco lugar para extenderse en explicaciones sobre el sacerdocio". La figura dominante en el Apocalipsis es el Cordero, que es víctima. Pero "es una víctima viva, un víctima que se adelanta como para ofrecerse. Es, por tanto, una víctima que desempeña por sí misma el papel de sacerdote" (J. Comblin, Cristo en el Apocalipsis, op. cit., pp. 265 y s.).

30. Según Contreras, El Señor de la vida, op. cit., p. 57, "Jesús es llamado 'el Viviente' (Ap 1, 17.18), porque participa enteramente de la vida misma de Dios, designado en el libro del Apocalipsis por antonomasia como 'el Viviente'. Esta vida se ha manifestado, ya desde el comienzo, en la obra resplandeciente de la creación (Ap 4, 11; 10, 6) y absolutamente en el reinado sacerdotal que Dios y Cristo han instaurado, merced al misterio pascual del Cordero degollado, pero de pie $(11,15 ; 12,10 ; 11,17 ; 19,6 ; c f r$. de modo especial los dos primeros textos); asimismo, esta vida tiene una cualidad altamente significativa: es eterna"; cfr. también J. Comblin, Cristo en el Apocalipsis, op. cit., pp. 275-323. 
definitiva, la Vida, de la que él mismo goza ya plenamente, o de condenarles, con un poder que es más bien propio de Dios.

\section{La segunda visión del semejante a un Hijo de hombre en Ap 14, 14}

Lo que se ha dicho en la primera visión del "hijo de hombre" viene completado en una segunda visión en Ap 14, 14. El texto se encuentra en el centro de una visión (Ap 14, 6-20) ${ }^{31}$, que refleja la típica estructura septenaria, propia del Apocalipsis, y que introduce el septenario de las copas. Como nota con acierto J. Roloff ${ }^{32}$, la aparición del "hijo del hombre" en el v. 14 está enmarcada por la visión de tres ángeles, tanto antes (cfr. vv. 6-13) como después ( $c f r$. vv. 15-20) de la manifestación del hijo del hombre. De acuerdo con un motivo propio de la literatura apocalíptica (cfr. 1 Henoc y 4 Esdras 13), aquí se atribuye al "hijo del hombre", que ya hemos visto es Cristo $^{33}$, la potestad de juzgar: "Volví a mirar y vi una nube blanca. Sentado sobre la nube estaba un ser de aspecto humano con una corona de oro sobre la cabeza y una hoz afilada en la mano" (Ap 14, 14). Los seis ángeles del resto de la visión, en cambio, son cada vez denominados "otro ángel".

Por otro lado, si el hijo del hombre está sentado sobre una nube (también en Dan 7, 13 el hijo del hombre viene sobre las nubes; $c f r$. Mc 14,62) y la nube es un atributo de la divinidad ${ }^{34}$, estamos ante un motivo que acompaña las revelaciones de Dios ( $c f r$. Ex 16, 10; Nm 11, 25) o que es utilizado como medio de transporte divino (cfr. Dt 33, 26; Is 19, 1; Sal 104, 3; cfr. Mc 13, 26), y que invita, por tanto, a descubrir la divinidad del hijo del hombre, identificado en el Apocalipsis con Cristo. Mientras que el hecho de que está sentado destaca su autoridad para juzgar. Y recuerda, subrayando así la extraordinaria dignidad de Cristo (en Ap 4-5 es Dios el que está sentado sobre el trono), que según Is 19, 1, también Dios entra en Egipto sentado sobre una nube para juzgarlo ( $c f r$. también lo que dice Joel 4, 12 a propósito del juicio de las naciones).

Si en la visión anterior (Ap 14, 1-5), que no por casualidad empieza exactamente con la misma fórmula con que empieza Ap 14, 14 (kaì eîdon kai idoú), Cristo aparecía como el Cordero de pie (resucitado) en el monte Sión, en compañía de todos los salvados, "que tenían su nombre y el nombre de su Padre escrito en la frente" (Ap 14, 1b), aquí aparece el "hijo del hombre" en su dimen-

31. Un buen análisis de esta visión la encontramos en K. Huber, Einer gleich einem Menschensohn, op. cit., pp. 218-269.

32. Cfr. J. Roloff, Die Offenbarung des Johannes, Würzburg, ${ }^{22001, ~ p . ~} 151$.

33. Eso es lo que defiende también K. Huber, Einer gleich einem Menschensohn, op. cit., p. 243 ( $c f r$. pp. 242-244), cuando analiza quién es realmente la figura que aparece en Ap 14, 14: "Die Figur des Menschensohngleich steht für den erhöhten Christus".

34. En la transfiguración de Jesús, Dios habla desde la nube ( $c f r$. Mc 9, 7 par). La nube aparece 7 veces en el Apocalipsis, cuatro de ellas en Ap 14, 14-16. Las tres restantes (Ap 1, 3; 10, 1 y 11, 12) la relacionan también con el mundo divino. 
sión de rey, con una corona de oro sobre su cabeza. De hecho, también al jinete del caballo blanco, Cristo, en Ap 6,2, se le da una corona para vencer, como también los 24 ancianos que, según Ap 4, 4 están vestidos de blanco y sentados sobre tronos, llevan coronas de oro sobre sus cabezas; de los saltamontes, en cambio, que son descritos en Ap 9, 7, se dice que llevan solo como (hôs) coronas semejantes (hómoioi) al oro.

Pero en este texto, el "hijo del hombre" aparece también en su dimensión de juez universal, con una hoz afilada en su mano, a punto de juzgar y de condenar al imperio romano (representante simbólico de todo imperio), que no se quiere convertir. Un juicio para el que se emplean dos imágenes: la del ángel que invita a meter la hoz ${ }^{35}$ para la siega (cfr. Ap 14, 15-16) y la del que invita a meter la hoz para la vendimia ( $c f r$. Ap 14, 17-20). Esta potestad que tiene el hijo del hombre, Cristo, para juzgar es uno de los aspectos significativos de la cristología del Apocalipsis. Un juicio que, si bien se empieza a anticipar ya en este mundo con las plagas y la destrucción del Imperio romano ( $c f r$. Ap 15-18; $c f r$. Jer 51, 33 en relación con Babilonia), apunta, de acuerdo con el significado que suele tener la cosecha en el Antiguo ( $c f r$. Joel 4, 13; Is 27, 12) y en el Nuevo Testamento ( $c f r$. Mt 3, 12; 13, 24-30.36-43), sobre todo al juicio divino al final de la historia. Y si en Ap 14, 20 ( $c f r$. Is 63, 23) Juan afirma que "el lagar fue pisado en las afueras de la ciudad, y salió de él tanta sangre que alcanzó la altura de los frenos de los caballos en un radio de mil seiscientos estadios" (cfr. también 1 Hen 100, 1-3), con ello se alude, por un lado, a la decisiva batalla escatológica de Dios contra sus enemigos ante las puertas de Jerusalén ( $c f r$. Joel 4, 9-11.14; Zac 14, 2-4; 4 Esd 13, 33-35; 2 Bar 40, 1); y por otro lado, se subraya la enormidad del baño de sangre, simbolizado por la altura hasta la que llega la sangre ("hasta los frenos de los caballos") "en un radio de mil seiscientos estadios" (un número claramente simbólico, pues es la multiplicación de cuatro por cuatro por cien; y 300 estadios equivalen a unos $300 \mathrm{~km}$ ). Se trata, entonces, de un juicio universal.

Y no es casual que Cristo, el hijo del hombre, esté en el corazón de este juicio, pues con ello se ha preparado la visión final de Cristo, montado en un caballo blanco (cfr. Ap 19, 11-16), que culmina en su triunfo definitivo contra la Bestia (que en Ap 12-13 es presentado como la contrafigura de Cristo) y el falso profeta (cfr. también Ap 13, 11-17), que son "arrojados vivos al estanque ardiente de fuego y azufre" (Ap 19, 20), mientras el resto de los enemigos de Dios "fueron exterminados por la espada del que montaba a caballo" (Ap 19, 21). Notemos que la espada salía de la boca de Cristo, en alusión a lo que ha dicho antes en Ap 1, 16; 2, 16, y que se encarna en la palabra del Evangelio, que convierte al que la asimila en profeta ( $c f r$. Ap 10, 9-10). En esta visión final de Cristo, este, que es la

35. ¡La palabra "hoz" (drépanon) aparece 7 veces en el Apocalipsis, siempre en contexto de juicio! El autor se habrá inspirado en Joel 4, 13. 
Palabra de Dios (Ap 19, 13), aparece como el vencedor definitivo que ejecuta el juicio de Dios $^{36}$.

\section{Títulos de Cristo a lo largo del Apocalipsis}

Pero los títulos atribuidos a Cristo no aparecen solo en estas visiones que acabamos de citar, sino que se distribuyen también a lo largo de toda la obra. Jesús es el que tiene las siete estrellas en su mano derecha y anda entre los siete candelabros de oro (Ap 2,1), que aparece con las características del "Hijo del hombre" de Daniel ( $c f r$. Dan 7, 13), incluida la de juzgar al final sobre el bien y el mal que se ha realizado en la tierra $(c f r .1,12 ; 14,14$; es lo que presuponen también las advertencias de Jesús a las distintas Iglesias en Ap 2-3). Es el primero y el postrero, el que estuvo muerto y vivió (Ap 1, 18; 2, 8), el principio de la creación de Dios (Ap 3, 14; cfr. Col 1, 15). Es el que tiene la espada aguda de dos filos (Ap 2,12). Es el Hijo de Dios y el que tiene los ojos como llama de fuego y los pies como bronce bruñido (Ap 2, 18). Es el que tiene los siete espíritus de Dios y las siete estrellas $(3,1)$. Es el Santo (un título referido a Dios en Ap 4, 8; 6.10), el Verdadero, el que tiene la llave de David ( $c f r$. Is 22,22$)$, el que abre y ninguno cierra, y cierra y ninguno abre (Ap 3, 7). Es el Amén, el testigo fiel y verdadero, el principio de la creación de Dios (Ap 3, 14). Es el león de la tribu de Judá (cfr. Gn 49, 9), la raíz de David (Ap 5, 5; cfr. Is 11, 10). Es llamado Fiel y Verdadero (Ap 19, 10) y su nombre es la Palabra de Dios (Ap 19, 13; $c f r$. Jn 1, 1-4.14) ${ }^{37}$. Es el Alfa y la Omega, el principio y el fin, el primero y el último (Ap 22, 11), lo cual muestra su relación íntima con Dios, antes de la creación del mundo. Es la raíz y el vástago de David, es decir, el Mesías anunciado, y la estrella radiante de la mañana (Ap 22, 16; $c f r .2,28$ ). Y reinará por los siglos de los siglos (Ap 11, 1). Por último, notemos también que en Ap 21, 6 se aplica a Cristo lo que Is 55, 1 ponía en boca de Dios: "Al que tenga sed, le daré a beber gratis de la fuente del agua de la vida". Y en Ap 2, 23 se dice de él que nos juzgará según las obras, algo que el Sal 62, 13 considera que es propio de Dios.

\section{Divinidad de Cristo}

Algunos de estos títulos, y más si se tiene en cuenta la cercanía de este texto a otros que encontramos en el cuarto Evangelio, muestran la intima unión de Jesucristo con Dios y su carácter, en principio, divino ${ }^{38}$. Comblin lo destaca

36. El poder de la palabra de Cristo lo destaca bien K. Huber, Einer gleich einem Menschensohn, op. cit., pp. 301-306, continuando un motivo que ya encontramos en el Antiguo Testamento en relación con la palabra de Dios (cfr. Is 49, 2; 11, 4; 55, 11).

37. Sobre el significado de "la palabra de Dios" en el Apocalipsis, cfr. J. Comblin, Cristo en el Apocalipsis, op. cit., pp. 122-136.

38. "Como en el cuarto Evangelio, la persona de Cristo es netamente una persona divina, sin que esta divinidad perjudique a la realidad de su humanidad" (J. Comblin, 
cuando, a propósito del Apocalipsis, escribe: "Está fuera de duda que entre sus intenciones primordiales, una de las primeras es la de mostrar la divinidad de Jesús. Fuera del cuarto Evangelio, ningún libro del Nuevo Testamento es tan claro en este punto" 39 .

Por eso se dice de Jesucristo que merece la gloria, que en principio es algo propio de Dios (Ap 7, 12; 14, 7; 19, 6-7; 15, 3; cfr. Ap 5, 12.13, referido al Hijo; y en Ap 1, 6, cuando confiesa: "a él la gloria y el poder por los siglos de los siglos", no queda claro si se está hablando del Padre o del Hijo). En todo caso, se atribuye al Hijo algo que, en principio, es propio solo de Dios.

Y del Hijo se dice también que merece el poder, igual que lo merece el Padre que está sentado en el trono (Ap 5, 12: “iEl Cordero que está degollado merece todo poderío y riqueza, saber y fuerza, honor, gloria y alabanza!"). El poder es algo que, en principio, también es propio de Dios (cfr. 1 Cron 16, 27; Job 12, 13; Sal 59, 16; Rm 1, 20; 1 Co 1, 18; 1 Pe 1, 4). Ya en Ap 4, Dios había sido revelado por el Espíritu (Ap 4, 2) como "el que estaba sentado en el trono" y que "parecía de jaspe y granate, y el trono irradiaba todo alrededor un halo que parecía de esmeralda" (Ap 4, 3). Él es el Señor y Dios nuestro, que merece recibir la gloria, el honor y la fuerza, pues ha creado el universo ( $c f r$. Ap 4, 11). Por eso sorprende que el cap. 5 concluya con un himno, en el cual se identifica la alabanza a Dios y la del Cordero: “ $\mathrm{A} \mathrm{Al}$ que está sentado en el trono y al Cordero, la alabanza, el honor, la gloria y el poder por los siglos de los siglos! (Ap 5, 13) ${ }^{40}$.

El profeta Juan refiere también a Cristo $(c f r$. Ap 5,13$)$ la alabanza, que se atribuye claramente a Dios en Ap 19, 5 (cfr. Ex 15, 2; 1 Cron 16, 8; Sal 30, 12; 67, 3.5; 93, 1; 106, 1; 148, 13; Mt 11, 25; Lc 10, 21; Ef 5, 19), confirmando así la alta cristología que es propia del autor del Apocalipsis. En este contexto, no sorprende, entonces, que si en Ap 15, 4 ha dicho de Dios Padre que solo Él es santo, en Ap 3, 7 Jesús reciba el calificativo de "Santo". Como también resulta significativo que si el trono es el lugar por excelencia desde el cual reina Dios Padre ( $c f r$. Ap 4, 2ss), en Ap 22, 1 se hable de "un río de agua viva, transparente como el cristal, que salía del trono de Dios y del Cordero". Ya antes nos había dicho que el Cordero degollado, pero en pie ( $c f r$. Ap 5,6), se encontraba en medio del trono y es adorado por los cuatro seres vivientes y los veinticuatro ancianos (cfr. Ap 5, 8), al igual que antes se ha dicho que adoraron a Dios, que estaba sentado en el trono (cfr. Ap 4, 10).

Cristo en el Apocalipsis, op. cit., p. 37); cfr. también K. Huber, Einer gleich einem Menschensohn, op. cit., pp. 284-289.

39. J. Comblin, Cristo en el Apocalipsis, op. cit., p. 269; cfr. pp. 269-273.

40. F. Contreras (El Señor de la vida, op. cit., p. 269) subraya también que "el último capítulo del libro $(22,2-3)$ hace mención del único trono de Dios y del Cordero; ambos comparten la misma gloria de la divinidad". 
En la misma línea de la unión profunda entre el Padre y el Cordero se encuentra la afirmación de Ap 21, 22 de que en la ciudad celestial no hay templo alguno, "pues el Señor Dios todopoderoso y el Cordero son su templo" (Ap 21, 23).

Lo que acabamos de ver sobre la relación íntima entre el Padre y el Hijo tiene su confirmación, sobre todo si se tiene presente que el Apocalipsis hay que verlo en el marco de la teología joánica, aunque su autor no sea el evangelista, en el hecho de que Jesús recibe el título Lógos, de Palabra de Dios (Ap 19,13), de tan hondo contenido en el cuarto Evangelio ( $c f r$. Jn 1, 1-18). Se trata, como indica el profeta en Ap 19, 12, de "un nombre que solo él puede descifrar", pues el nombre nos revela la esencia de la persona y es entonces obvio, si el autor presupone la divinidad de Jesús, que nadie es capaz de descifrarlo, si Jesús mismo no lo da a conocer.

En este contexto, el hecho de que Jesús reciba el título de "Rey de reyes y Señor de señores" (Ap 19, 16; cfr. 17, 14) no solo implica una clara crítica del emperador Domiciano, que se hacía aclamar como "dominus ac deus" (señor y dios), sino, además, la confesión implícita de la divinidad de Jesucristo, supuesto que el título de Señor (kyrios) es un título que el Antiguo Testamento aplica a Dios para traducir el nombre de Yahvé. El Apocalipsis lo atribuye tanto al Dios todopoderoso ( $c f r$. Ap 1, 8; 4, 8; 18, 8) como aquí al Hijo, lo cual explica que Dios lo gobierne todo a través de Jesucristo.

Por otro lado, es el Cordero degollado el que ha realizado la Alianza (la Primera Alianza la había realizado Dios con Israel, según Ex 19-24) con el nuevo pueblo de Dios, un pueblo que él ha adquirido para Dios con su sangre y ahora está formado por hombres de toda raza, lengua, pueblo y nación" (Ap 5, 9), pues estos son "los que han lavado y blanqueado sus túnicas en la sangre del Cordero" (Ap 7, 14).

Esta íntima relación entre el Padre y el Cordero degollado de pie ante el trono de Dios aparece también en otros lugares, donde se habla, por ejemplo, de que la salvación pertenece a Dios y al Cordero $(c f r$. Ap 7, 10) o de que "la ciudad no tiene necesidad de sol ni de luna que brillen en ella; porque la gloria de Dios la ilumina, y el Cordero es su lumbrera" (Ap 21, 23; cfr. Is 60, 19). En la misma línea, se dice que un río limpio de agua de vida, resplandeciente como cristal, salía del trono de Dios y del Cordero ( $c f r$. Ap 22, 1), destacando también que "el trono de Dios y del Cordero estará en ella [en la Jerusalén del cielo] y sus siervos le rendirán culto" (Ap 22, 3). El significado del Cordero para la vida eterna de los salvados aparece, finalmente, en el hecho de que es el Cordero el que tiene el libro de la vida (cfr. Ap 21, 27b).

El cúmulo de textos que acabamos de citar, espero que nos haya convencido no solo de la unión íntima entre Jesús y el Padre, sino también del significado cristológico fundamental que tiene el Apocalipsis. 


\section{Jesús como revelador del curso de la historia y del sentido de la vida humana}

En este segundo apartado, quiero destacar otro aspecto de la cristología del Apocalipsis, que aparece claramente en Ap 5, el cual, en cuanto es la introducción al segundo septenario, el del libro con siete sellos (Ap 5, 1-8, 1), es como la introducción a la parte central y fundamental del libro, que incluye también el septenario de las trompetas (Ap 8, 2-14, 5) y el de las copas (Ap 14, 6-19, 8) ${ }^{41}$.

El libro que tiene en su mano derecha el que está sentado en el trono ( $c f r$. Ap 5, 1), un pergamino enrollado, escrito por el anverso y el reverso, y sellado por siete sellos, se refiere probablemente a la historia del mundo ${ }^{42}$. Si está con 7 sellos, significa que apenas se puede leer, es decir, conocer, nada de lo que está escrito en él, pues solo se puede ver una parte muy superficial. Con ello, el autor nos está diciendo que solo Dios conoce dicha historia en su realidad más honda, por lo cual esta no puede ser conocida si no es revelada. Pero si en Ap 5, 7 Juan nos indica que el león de Judá, el retoño de David, es decir, Jesús, abrirá el rollo y sus siete sellos, esto significa que Dios le ha dado a conocer el sentido de la historia y que a través de él quiere revelarlo a sus siervos, que forman las Iglesias a las cuales Juan dirige su libro, pues él es el Vencedor gracias a su muerte redentora.

El título de Vencedor, aplicado a Jesús, es muy significativo en el Apocalipsis, dentro del marco del enfrentamiento entre las Iglesias de Cristo y el Imperio romano. Comblin ${ }^{43}$ lo comenta así:

Ya hemos dicho que la victoria del Cordero se situaba en primer lugar en el contexto del juicio. Prolonga el tema bíblico de la intervención soberana de Dios en la historia para ejercer su justicia.

Hemos visto también cómo el Hijo del hombre se revestía en el Apocalipsis de los atributos imperiales y se presentaba así como juez y sucesor de los emperadores romanos después del juicio. San Juan prolongaba así la línea bíblica de Daniel 7, donde el Hijo del hombre instala su reino sobre las ruinas

41. Sobre la estructura del Apocalipsis, una estructura concéntrica, muy bien pensada, que ayuda a comprender mejor el mensaje del libro, $c f r$. X. Alegre, Memoria subversiva y esperanza para los pueblos crucificados, op. cit., pp. 56-65.

42. "Este libro representa el proyecto misterioso de Dios sobre la historia" (F. Contreras, El Señor de la vida, op. cit., p. 264). La importancia de la intervención de Cristo en la historia la destaca también Contreras (ibid., p. 344), cuando afirma que "el Apocalipsis representa un drama sacro: la historia de la salvación, contemplada idealmente desde los ojos providentes de Dios y vivida en sus fases cambiantes de sentido", pues "el Apocalipsis no es un tratado dogmático, sino un libro misterioso que intenta hablar de la intervención decisiva de Cristo en el mundo con el balbuceante lenguaje de las imágenes" (ibid., p. 345).

43. J. Comblin, Cristo en el Apocalipsis, op. cit., p. 266. 
de los imperios que han constituido la historia temporal y el preludio de la historia divina.

Y añade ${ }^{44}$ :

Cuando el Cordero, el león de la tribu de Judá se presenta en el palacio celestial de Dios para inaugurar su reinado $(5,5)$, llega como vencedor. Y san Juan evoca con esto no solamente la victoria que ha reportado sobre los adversarios de Dios, sino también un atributo imperial que lo califica desde ahora como victorioso, invictus, para siempre y desde el tiempo presente, revestido de una dignidad imperial que no carece de repercusiones en el transcurso de la historia.

En el conjunto del Apocalipsis, el profeta Juan quiere que miremos con ojos críticos la historia. Quiere que tomemos conciencia de los males del mundo, provocados fundamentalmente por el egoísmo de los imperios políticos, en alianza con los económicos y sociales, sin dejarnos engañar por la falsa propaganda del imperio ( $c f r$. Ap 13, 11-14), a la que en Ap 20, 10 denomina "el falso profeta". En este contexto, Jesús no solo desenmascara el mal que hay en el mundo, sino que es visto como el gran Liberador ( $c f r$. Ap 7, 13), pues viene a liberarnos de los males que nos amenazan, fundamentalmente a través del Imperio romano, que persigue a los cristianos, los margina $\mathrm{y}$, a veces, asesina (cfr. Ap 6, 9-13; 13, 15-17).

Él es, entonces, por un lado, el que, más allá de la muerte, "los apacentará y los conducirá a fuentes de aguas vivas, y Dios enjugará las lágrimas de sus ojos" (Ap 7, 17; cfr. 21, 1-4; 22, 1-5). Pero, por otro lado, es el que, ya aquí, en este mundo, se enfrenta al mal, representado por Roma. El enfrentamiento entre Cristo y el imperio, en el fondo, es un enfrentamiento a muerte, pues el imperio es la mano derecha de Satanás, el dragón rojo, en esta lucha a muerte entre el bien y el mal, que se realiza en este mundo ( $c f r$. Ap 12-13).

Este enfrentamiento ya empezó durante la vida de Jesús. Esto es lo que Juan expresa simbólicamente en Ap 12, 4b-5, cuando dice: "Y el dragón se puso al acecho delante de la mujer que iba a dar a luz, con ánimo de devorar al hijo en cuanto naciera. La mujer dio a luz un hijo varón, destinado a regir todas las naciones con vara de hierro, el cual fue puesto a salvo junto al trono de Dios". Lo que simbólicamente quiere expresar el profeta Juan aquí es la equivalencia de lo que significa la exaltación de Jesús, como triunfo en la cruz, en el cuarto evangelista ( $c f r$. Jn 3, 14; 8, 28; 12, 32-33) ${ }^{45}$. Matando a Jesús en la cruz, el dragón rojo confía en que acabará con él. Pero Jesús fue arrebatado, exaltado, al cielo, con lo cual el demonio no solo no acabó con Jesús, sino que posibilitó su triunfo

44. Ibidem.

45. Cfr. ibid., pp. 118-120. 
definitivo en la Resurrección. Ante este fracaso del mal, la Iglesia, obviamente, sufre las consecuencias, pues al no poder acabar con Jesús, el dragón persigue a la mujer, que simboliza a la Iglesia (cfr. Ap 12, 1-2.13-18), la cual, sin embargo, "huye al desierto", es decir, es protegida por Dios (Ap 12, 6).

Si Jesús, entonces, es el que puede romper los sellos, esto significa que nos revela, en el segundo septenario del Apocalipsis (5, 1-8, 1), cuáles son las fuerzas, positivas y negativas, que intervienen en la historia, facilitando así que la comunidad cristiana pueda ser lúcida ante los acontecimientos que están ocurriendo en el mundo. Jesús está representado por el jinete que aparece montado en el caballo blanco (Ap 6, 1-2) ${ }^{46}$ y del cual se revela que acabará venciendo a las fuerzas del mal, simbolizadas por los caballos rojo, negro y amarillento (Ap 6, 3-8). Notemos que Ap 6, 1-2 hace inclusión con la primera de las visiones del quinto septenario (Ap 19, 11-16), como para indicar en qué medida, desde la historia hasta la metahistoria, Cristo es el Señor y Salvador de sus siervos.

\section{La primera visión del quinto septenario (Ap 19, 11-16)}

En esta primera visión del quinto septenario ${ }^{47}$, se nos da como la quintaesencia de la actuación de Jesús en el mundo, uniendo su primera venida con la que será su segunda y definitiva. Jesús monta en un caballo blanco, como en Ap $6,1-2$, porque en esta reflexión final del quinto septenario, con la que se concluye el libro del Apocalipsis, Juan recuerda la actuación decisiva de Jesús en la historia, en una visión que es introducida con una fórmula de revelación ( $c f r$. Ez 1, 1; Mt 3, 16; Hech 7, 56; Jn 1, 51). De Jesús se vuelve a afirmar que es fidedigno y veraz (Ap 19, 11b) y que juzga y combate al mundo con justicia (Ap 11, 19c), a diferencia del imperio que es como la encarnación de la injusticia.

Como en la visión inicial (cfr. Ap 1, 9-20), aquí se vuelve a recordar que nada escapa al conocimiento de Jesús, diciendo que "sus ojos son como llamas de fuego" (Ap 19, 12a). Y se subraya su poder con la imagen de las múltiples diademas que adornan su cabeza ( $c f r$. Ap 19, 12b), mientras que su carácter

46. El jinete que monta el caballo blanco es Jesús, como lo muestra no solo el color blanco y la inclusión con el jinete de 19, 11-16, sino también el hecho de que sale para vencer y su arma, el arco, no es recogido en el resumen de Ap 6, 8: $c f r$. M. Bachmann, "Der erste apokalyptische Reiter und die Anlage des letzten Buches der Bibel”, Biblica, 67 (1986), pp. 240-275; Id., "Noch ein Blick auf den ersten apokalyptischen Reiter (von Apk 6, 1-2)”, NTS, 44 (1998), pp. 257-278; U. Vanni, Apocalipsis. Una asamblea litúrgica interpreta la historia, Estella, 1994, pp. 100 y s.; bibliografía sobre el tema puede encontrarse en O. Böcher, Die Johannesapokalypse, Darmstadt, ${ }^{4} 1998$, pp. 47-56. Las razones en contra que da, p. ej., K. Huber, Einer gleich einem Menschensohn, op. cit., pp. 10 y s., no me parecen convincentes.

47. Según T. B. Slater, Christ and Community, op. cit., p. 230, en Ap 19, 11-21 tendríamos "the christological high point of the book". 
divino se expresa diciendo que "lleva escrito un nombre que solo él sabe descifrar" (Ap 19, 12c). En buena teología joánica (el cuarto Evangelio subraya que es precisamente en la muerte/exaltación de Jesús donde este triunfa y lleva a plenitud la salvación universal: $c f r$. Jn 3, 14; 8, 28; 12, 32-33), el profeta Juan recuerda también el significado profundo de la cruz de Jesús en este triunfo, cuando indica de Jesucristo que "va envuelto en un manto empapado de sangre" (Ap 19, 13a) y que "su nombre es palabra de Dios" (Ap 19, 13b). De hecho, "los ejércitos del cielo, con sus jinetes vestidos de lino blanco purísimo, galopan tras sus huellas sobre blancos caballos" (Ap 19, 14; el destacado es mío).

Pero es interesante notar cómo logra Jesús su victoria sobre sus enemigos. Su fuerza está precisamente en el poder de su palabra (Ap 19, 15: "De su boca sale una espada afilada para herir con ella a las naciones a las que va a gobernar con vara de hierro"), algo que Juan ya ha preparado cuando, en el corazón mismo del tercer septenario, el de las trompetas, que es una llamada a la movilización cristiana contra el imperio, ha insistido en que la manera como el cristiano vencerá al imperio no será con la violencia de las armas, sino siendo profeta, algo que se logra cuando uno asimila plenamente el Evangelio (lo "come"), simbolizado por el librito de Ap 10. Una asimilación que, de entrada, es dulce como la miel, ya que el contenido del Evangelio es una maravilla, pero que luego se vuelve amargo, pues si uno lo encarna en su vida, ello le comportará la persecución por parte del imperio ( $c f r$. Ap 10, 9-10; $c f r$. la vocación del profeta Ezequiel: Ez $3,3.14$ ), como pudo experimentarlo en carne propia, en tanto que fue un buen seguidor de Jesús, Mons. Óscar A. Romero ${ }^{48}$.

De Jesús, por tanto, no solo se dice que revela lo que está ocurriendo en el mundo, sino que con la ayuda del Evangelio, simbolizado por el librito de Ap 10, llama a la rebelión creyente contra el imperio, convirtiendo a los cristianos y cristianas en profetas $\left(c f r\right.$. Ap 11, 1-14) ${ }^{49}$, que con su testimonio contribuirán eficazmente a la caída del imperio. Pues si bien es verdad que este aparentemente los vencerá y convertirá en mártires ( $c f r$. Ap 11, 7-10), sin embargo Dios los resucitará y desde el cielo contemplarán la destrucción de sus enemigos (cfr. Ap 11, 12-13; también 16, 17-18, 24). Un castigo que será ejecutado también por Jesús, ya que Dios le ha entregado el poder de salvar y condenar, pues "él es quien pisa el lagar donde destila el vino de la ardiente ira del Dios todopoderoso" (Ap 19, 15b). Y es presentado como el Hijo del hombre apocalíptico.

48. Cfr. X. Alegre, "Mons. Ó. A. Romero, un defensor profético de los derechos humanos", en X. Alegre, P. Trigo, F. Gonsalves y J. Sobrino, El monseñor Romero de todos, San Salvador, 2011, pp. 9-38 (Cuadernos Centro Monseñor Romero, n. ${ }^{\circ}$ 27).

49. "Los dos testigos son figura de la Iglesia. Su función profética es función de la Iglesia. La ejercen delante de Roma, en el Imperio romano, al que "se llama, en sentido espiritual, Sodoma o Egipto", es decir, el país de la idolatría y de la impureza $(11,8)$ " (J. Comblin, Cristo en el Apocalipsis, op. cit., p. 133). 
En este sentido, parece que también es Jesús el ser de aspecto humano que está sentado sobre una nube blanca, tiene una corona de oro en su cabeza y una hoz afilada en la mano para segar la tierra (cfr. Ap 14, 14-16). En todo caso, las plagas que caen sobre la tierra, escritas en el cuarto septenario, el de las copas (cfr. Ap 14, 6-19, 8), son una llamada a la conversión del imperio (como las plagas del Éxodo habían pretendido, inútilmente, la conversión del faraón).

Desgraciadamente, este no escuchará la llamada y acabará siendo destruido por los mismos males que él ha causado en los demás ( $c f r$. Ap 17-18). Y con ello sellará su condenación y la pérdida de su poder, pues solo Jesús es el auténtico "Rey de reyes y Señor de señores" (Ap 19, 16). Para el profeta Juan, el auténtico señor de la historia no es el emperador Domiciano, aunque ahora parezca que tiene las de ganar y persiga a los cristianos, sino el "Cordero degollado, de pie (resucitado) ante el trono de Dios". Por eso es tan importante que el cristiano no se deje engañar por la falsa propaganda del imperio y se mantenga fiel a los valores encarnados en el Evangelio de Jesús.

\section{Jesús como el protector amoroso y guía crítico de la Iglesia}

El primer septenario del Apocalipsis, el de las siete cartas (Ap 1, 9-4, 11) presenta a Jesús que, como protector (¡tiene a sus Iglesias en su mano derecha!, según Ap 1, 16.20; $c f r .2,1)$ y Señor de la Iglesia, se hace presente y actúa eficazmente en ella ${ }^{50}$. Y la interpela para que supere sus infidelidades y vuelva a ser fiel a su amor primero ( $c f r$. Ap 2, 4-5), a la vocación que ha recibido, pues por su muerte en la cruz, Cristo ha constituido a los cristianos en reino y los ha hecho sacerdotes para Dios, su Padre (Ap 1, 5-6; cfr. 1 Pe 2, 9).

El hecho de que sean reino y sacerdotes recuerda lo ocurrido con el pueblo de Dios, Israel, en la primera Alianza en el Sinaí ( $c f r$. Ex 19, 6). El don de la liberación lleva a Dios a hacer una Alianza con el pueblo, según la cual, y como respuesta al don previo de Dios (cfr. Dt 26, 5-10.11-13), el pueblo se convertirá en el instrumento de Dios para mostrar a todos los pueblos de la tierra que otro modo de vivir, solidario y no egoísta, es posible, de modo que no haya pobres en medio del pueblo porque cada cierto tiempo se perdonan las deudas y todos comparten ( $c f r$. Dt 15; Lv 25). Cristo es, para Juan, el que ha constituido a los cristianos en pueblo de Dios y en instrumento, por tanto, de su acción liberadora en el mundo.

En todo caso, y esta es la característica fundamental de Jesús con respecto a su(s) Iglesia(s), estas son fruto de la acción creadora de Jesús, que la(s) ama

50. Cfr. F. Contreras, El Señor de la vida, op. cit., p. 343: "Se subraya la intervención de Cristo glorioso en su Iglesia. La historia de Jesús no se limita a su etapa de encarnación terrena, continúa como Señor, actuando con autoridad en la marcha de la Iglesia, a la que purifica con su palabra y conduce hasta su realización escatológica". 
(cfr. Ap 1, 5a). Y la prueba de ello es que ha rescatado con su sangre a los que están esclavizados por los pecados ( $c f r$. Ap 1, 5b). En este contexto, conviene tener presente que la cruz de Jesús, como recuerda el evangelista Juan, es la mayor prueba de amor, por cuanto nadie ama más que el que da la vida por los demás ( $c f r$. Jn 15, 13). Y de este amor de Jesús brota el amor a los hermanos ( $c f r$. Jn 13, 14-15.34-35), aunque ello comporte la persecución (cfr. Jn 15, 18-21), algo que las Iglesias están sufriendo ahora duramente en carne propia.

Pero Cristo no ama a la Iglesia por los méritos de esta, pues Jesús conoce perfectamente la situación de sus Iglesias ( $c f r$. Ap 1, 2-3-9.13.19; 3, 1.8.15). Sabe que son una mezcla de santidad y de pecado. Pero no por eso deja de amarlas, sino que da su vida gratuitamente por sus pecados (cfr. Ap 1, 5).

Pero precisamente porque ama a los suyos, a los que forman su Iglesia, los corrige (cfr. Ap 3, 19; cfr. las cartas 1. a 3. a, 4. a, 5. a, 7.a). Para ello, el Jesús del Apocalipsis ayuda a sus Iglesias a tomar conciencia de lo que realmente son, de lo bueno y de lo malo que hay en ellas. Y las exhorta a la conversión para que puedan participar un día plenamente de su amor. Pues Cristo conoce bien a sus Iglesias ( $c f r$. Ap 2, 2-3.9.13.19; 3, 1.8.15). Y en cuanto es el Hijo del hombre, tiene la capacidad y el poder para amonestarlas y corregirlas (cfr. Ap 2, 5.10.16.25; 3, 2.3.11.18).

Forma, pues, parte de esta guía amorosa de la Iglesia que Jesús la ayude a tomar conciencia, tanto de lo que está realmente ocurriendo a su alrededor como de lo que está sucediendo dentro de la misma Iglesia, para que despierte del sueño de inconsciencia e insensibilidad en el que, a menudo, está sumergida. Pero quiere también que caiga en la cuenta, agradecidamente, de todo lo bueno que hay en ella, a fin de que esto la anime a seguir mejor a Jesús. En todo caso, la Iglesia ha de ser crítica con los engaños con los cuales la quiere seducir el Imperio romano y vivir su vocación profética, lo que provocará la persecución por parte del imperio, pero acabará haciéndolo caer si este no se convierte. ¡Y Juan sabe que ningún imperio se ha convertido hasta ahora, a pesar de las plagas que sufre, como ocurrió ya con el faraón egipcio, que no quería dejar salir al pueblo de Israel de su esclavitud!

En todo caso, y supuesto que, aparentemente, el que ahora triunfa es el Imperio romano y no Jesús y su Iglesia, lo cual podría llevar a esta a una auténtica crisis de fe y a la resignación frente a la injusticia, el profeta Juan tiene interés por destacar en las cartas que Cristo tiene el poder para juzgar a los seres humanos ( $c f r$. también Jn 5, 22-24). Tiene poder para condenar a las Iglesias que hayan perdido el amor primero ( $c f r$. Ap 2, 4, amenazándolas con que dejarán de ser su Iglesia, pues arrancará su candelabro ( $c f r$. Ap 2, 5). O para premiar a los cristianos que hayan sido fieles al proyecto de Jesús, un poder que recuerda al de Dios, un poder que va desde guardarlos en el momento de la prueba $(c f r$. Ap 3, 10) hasta darles a comer el árbol de la vida (cfr. Ap 2, 7), otorgarles la corona de 
la vida (cfr. Ap 2,10) o darles a comer el maná (cfr. Ap 2, 17), vestirlos con las vestiduras blancas, símbolo de la gloria definitiva ( $c f r$. Ap 3, 5), convertirlos en columna inconmovible en el templo de Dios ( $c f r$. Ap 3, 12), e incluso hasta llegar a sentarse con Jesús en el trono (cfr. Ap 3, 21). Con todas estas imágenes aparece claramente hasta qué punto Cristo ha venido a cumplir las promesas hechas por Dios a su pueblo, unas promesas que han quedado registradas en el Antiguo Testamento.

Consecuencia del amor previo y gratuito de Jesús es la elección de los cristianos que forman la Iglesia para que sean el pueblo de Dios, algo que por la acción del Hijo les convierte en un linaje real, sacerdotal, para el Dios y Padre de Jesús (cfr. Ap 1, 5b).

Sobre todo, Jesús otorga (y recuerda) a su Iglesia la misión profética que le ha sido confiada, pues viviéndola no solo resistirá al imperio, sino que contribuirá eficazmente a su caída ( $c f r$. Ap 10-11). Y le recuerda su dimensión universal, pues el reino de Jesús no se reduce solo a Israel, sino que abarca a todas las personas y naciones de la tierra ( $c f r$. Ap 5, 9; 7, 9; 12, 5; 21, 24.26). En este sentido hay, como señala Comblin ${ }^{51}$,

incompatibilidad entre la realeza de Jesús y la realeza de la Bestia, es decir, la realeza que confiere Satán al Imperio romano. Cristo sustrae las naciones a esta soberanía impía. Las arranca de una dominación atea e impía para hacer de ellas el cuerpo de su pueblo. Porque de todas las naciones toma Jesús los testigos de los que hará la nueva Jerusalén. Desde ahora son sacados de la soberanía de Satán para entrar en la condición de testigos, que los pone precisamente en oposición con esta soberanía.

En cuanto al reinado de Cristo, que dura mil años (cfr. Ap 20, 1-10), se refiere probablemente al tiempo en el cual los mártires cristianos reinan ya con Cristo en el cielo en espera del juicio final y del mundo nuevo y la tierra nueva al final de la historia ${ }^{52}$.

Y esta es la "Buena Noticia eterna" (Ap 14, 6), que Juan anuncia a sus Iglesias: Que Dios sigue amándolas, las protege, corrige y acompaña, de modo que a la larga el imperio no podrá triunfar y los que hayan sido fieles al Cordero degollado, de pie ante el trono de Dios, podrán gozar eternamente de la vida plena en el cielo nuevo y en la tierra nueva, en la nueva Jerusalén, en la que ya no habrá ni llanto, ni luto, ni dolor, ni muerte, sino felicidad eterna porque Dios se manifestará plenamente como el Dios-con-nosotros. Pues Jesús no solo escoge, protege y ama a su Iglesia, sino que se une con ella con una unión tan íntima que puede ser expresada simbólicamente con la imagen de la Iglesia como novia,

51. J. Comblin, Cristo en el Apocalipsis, op. cit., p. 267.

52. Cfr. ibid., pp. 300-306. 
esposa del Cordero (cfr. Ap 21, 9ss; cfr. 19, 7-9), una imagen que ya profetas como Oseas habían empleado para designar la relación de Dios con el pueblo escogido, Israel.

A la vez, las promesas que hace Jesús en las siete cartas a los miembros de su Iglesia, para que se conviertan y lo sigan fielmente ${ }^{53}$ (cfr. Ap 2-3), y que anticipan la promesa de la salvación definitiva (cfr. Ap 21, 1-22, 5), muestran que es Jesús mismo el que promete y regala la plenitud de la salvación (de la Vida) escatológica, que implica la comunión personal con Cristo ( $c f r$. Ap 2, 26-28; 3 , $21 ; 22,1-5)^{54}$.

\section{Conclusión}

Con lo dicho, espero que haya quedado claro por qué empecé afirmando que el libro del Apocalipsis es, ante todo, "una revelación de Jesucristo sobre Jesucristo" y, por tanto, un auténtico tratado de cristología (y de soteriología). O, con palabras de U. Vanni ${ }^{55}$, en el Apocalipsis, "Jesucristo es puesto en un primer plano. Es el testigo fiel, el que ve al Padre y lo muestra. Está presente en la comunidad, y por lo tanto en la historia".

Por eso, y a modo de conclusión, termino con dos textos de sendos autores que a mi juicio expresan bien el significado de Jesús en el Apocalipsis. El primero es de un gran especialista en el libro, U. Vanni, quien dice:

La comunión con Dios (la "morada de Dios con los hombres") se realiza a través de la reciprocidad nupcial, que se hace posible por Cristo-Cordero: es decir, a través de una presencia y una "mediación" activa de Cristo entre Dios y la humanidad. La relación entre los pueblos y Dios Padre es por tanto "mediada" por Cristo, su hijo.

La expresión la morada de Dios con los hombres. Pondrá su morada entre ellos remite al capítulo 1 de Juan, versículo 14, donde se dice: "La Palabra se hizo carne y puso su morada entre nosotros".

Por lo tanto, con Cristo, que se hace hombre y viene a habitar con nosotros, la Alianza avanzó, concluyó, gracias a Cristo-hombre. Cristo, actor, estimulador y protagonista de la Alianza, hace posible la constitución de la morada de

53. La interpelación, a partir de la cuarta carta, al final de la entrega, "el que tenga oídos, que escuche lo que el Espíritu dice a las iglesias" (cfr. Ap 2, 7.11.17.29; 3, 6.13.22; cfr. también 13,9-10) insiste en el hecho de que para poder participar plenamente de la salvación hay que tomar en serio lo que Jesús dice a la Iglesia y ponerlo en práctica. Y si el que interpela es el Espíritu, ello se debe a que Cristo es el que posee la plenitud del Espíritu ( $c f r$. Ap 3, 1; 5,6) y lo puede comunicar a su Iglesia.

54. Cfr. K. Huber, Einer gleich einem Menschensohn, op. cit., pp. 209-212.

55. U. Vanni, Apocalipsis. Culmen de la revelación, Bilbao, 2011, p. 41. 
Dios entre los hombres. Por lo tanto, en un primer golpe de ojo - en la línea del Evangelio de Juan-, identificamos una morada habitada por Cristo, donde sin embargo no se dice que esta morada esté "abierta" a los hombres: se deduce, de todo el contexto, pero no se dice explícitamente.

Aquí, en cambio, se explicita: "La morada de Dios con los hombres". Pero esta morada de Dios con los hombres no es otra cosa que aquello que completa la morada de Jesús, la misma morada que, con el desarrollo de la Alianza, se abrió a todos los hombres.

Acogiendo a todos los hombres en su morada, Jesús los conduce al Padre, a la gran morada de Dios-Trinidad, con todos los hombres y con todos los pueblos, con Cristo y con el Espíritu: el nuevo ideal de habitación y de convivencia simbolizado en la nueva Jerusalén. ${ }^{56}$

El segundo es del obispo Pedro Casaldáliga, quien en uno de sus sonetos traduce bien lo que la Buena Noticia eterna del Apocalipsis implica para la vida del cristiano:
$\mathrm{Al}$ acecho del Reino diferente, voy amando las cosas y la gente, ciudadano de todo y extranjero.
Y me llama tu paz como un abismo
mientras cruzo las sombras, guerrillero
del Mundo, de la Iglesia y de mí mismo.

Precisamente porque el proyecto de Jesús, lo que él denominaba el Reino/ Reinado de Dios, es un proyecto alternativo, que se contrapone a los falsos valores del imperio de turno, es que acabó en una cruz. Y a sus seguidores, en la medida que sean fieles a ese proyecto, los amenaza eso mismo ( $c f r$. Mc 8, 34; Jn 15, 18-21; 16, 1-4). Por eso, para el autor del Apocalipsis, todo cristiano que quiera ser fiel a su vocación de seguir realmente a Jesús está llamado a ser un guerrillero del mundo, de la Iglesia y de sí mismo, sabiendo, por la fe, que al final Jesús triunfará y que, por tanto, vale la pena vivir de acuerdo con el Evangelio, aunque con ello pongamos en juego la vida y acabemos siendo víctimas del imperio de turno.

56. Ibid., pp. 251 y s. 